\title{
Jejunal Biopsy in Infants and Underweight Children
}

\author{
ALEXANDER S. MCNEISH \\ From the Royal Hospital for Sick Children, Oakbank, Glasgow
}

Peroral biopsy of the small bowel mucosa in infants and small children has recently come under serious criticism, and has been adjudged a difficult and hazardous procedure unwarranted in the routine investigation of childhood coeliac disease (Sheldon and Tempany, 1966). The main reasons for this were (1) a failure rate of $35 \%$ and (2) a significant risk of perforation or haemorrhage. The perforation rate in a series of biopsies of children weighing less than $10 \mathrm{~kg}$. was $9 \%$, rising to $33 \%$ in infants weighing less than $6 \mathrm{~kg}$. (Partin and Schubert, 1966).

It is the purpose of the present paper to describe a technique which is safe, and achieves a $90 \%$ success rate, even in small or underweight infants. Moreover, it allows a biopsy to be taken readily from or beyond the proximal jejunum: this contrasts with the statement by Anderson (1966) that biopsies in children are rarely obtained beyond the duodenojejunal junction.

\section{Patients and Method}

In the past 18 months, upper intestinal biopsies were obtained from 96 children. Their ages and weights are summarized in Table I. A standard $0.8 \times 1.7 \mathrm{~cm}$.

TABLE I

Age and Weight Distribution

\begin{tabular}{c|c|c|c}
\hline Age & $\begin{array}{c}\text { No. of } \\
\text { Patients }\end{array}$ & Weight (kg.) & $\begin{array}{c}\text { No. of } \\
\text { Patients }\end{array}$ \\
\hline 0-6 months & 7 & $2 \cdot 0-3 \cdot 9$ & 2 \\
7-12 months & 9 & $4 \cdot 0-5 \cdot 9$ & 10 \\
13-18 months & 17 & $6 \cdot 0-7 \cdot 9$ & 14 \\
19-24 months & 9 & $8 \cdot 0-9 \cdot 9$ & 14 \\
\hline Total less than & 42 & Total less than & 40 \\
2 years & & $10 \mathrm{~kg} \cdot$ & \\
\hline 2-4 years & 35 & $10 \cdot 0-11 \cdot 9$ & 18 \\
5-10 years & 14 & $12 \cdot 0-15 \cdot 9$ & 15 \\
More than 10 years & 5 & More than $16 \cdot 0$ & 23 \\
\hline Total over 2 years & 54 & Total more than & 56 \\
& & $10 \mathrm{~kg}$. & \\
\hline
\end{tabular}

Crosby capsule with a $3 \mathrm{~mm}$. port was used on each occasion (Crosby and Kugler, 1957). The conventional polythene tubing was found to be too inflexible to

Received January 23, 1967. negotiate the curves of the infant's upper gastro-intestinal tract, and had the further disadvantage of ready 'kinking', especially if bitten. Portex radio-opaque tubing $\mathrm{RO} / 1$ (Portland Plastics Ltd., Hythe, Kent) overcame these difficulties. However, the walls of this tubing were too soft to form a firm flange after heating. Therefore a $1 \mathrm{~cm}$. length of standard polythene tubing with flared end was inserted into the lumen of the radio-opaque tubing until the ends were flush. Both tubes were then pulled together through the hole in the base of the capsule, and jammed in the usual way. A very firm attachment of the soft radio-opaque tubing to the capsule was thus obtained.

The material of surgeons' disposable rubber gloves was found to be a suitable, cheap, and readily available source of rubber diaphragms.

Infants less than 1 year old were sedated by a hypnotic dose of chloral hydrate. Older children were given a hypnotic dose of quinalbarbitone. A stiff-walled rubber tube was used to introduce the capsule into the upper oesophagus (Lanzkowsky, Wilson, and Lahey, 1963; W. M. McCrae, 1964, personal communication). The capsule was allowed to pass out of the stomach by peristalsis, with the patient in the conventional right lateral position. The position of the instrument was checked by screening on an image intensifier before firing (see discussion). A few $\mathrm{ml}$. saline were injected into the tubing, followed by a few ml. air to clear the saline. The instrument was fired by suction from a $20 \mathrm{ml}$. syringe. The plunger was withdrawn sharply to its full extent and released immediately, so that suction was not prolonged, thus minimizing the risk of perforation. The capsule was then retrieved by steady traction.

\section{Results}

By this method, a satisfactory specimen was obtained from each child, enough tissue being present in most cases for conventional histology and enzyme assay. 83 biopsies were taken from the first or second loop of jejunum, and 13 from the fourth part of duodenum.

Six patients required a second biopsy attempt, the first having failed on each occasion because the instrument had not passed through the pylorus after three hours. In a further two patients, a successful biopsy was performed at a third attempt (see discussion).

No other complications were encountered. 


\section{Discussion}

The morbidity from peroral intestinal biopsy is small, at least in adults (Sheehy, 1964). The most serious complications are gastro-intestinal bleeding or frank perforation. McDonald (1966), when reporting a case of perforation and haemorrhage in a 4-year-old boy, was able to find published records of 21 haemorrhages and 25 perforations following intestinal biopsy, approximately one-third having occurred in children. He suggested that physiologically a child was an increased biopsy risk because of thinness of the submucosa and muscularis externa in the upper intestine.

Partin and Schubert (1966) described a series of 83 biopsies in 51 children, using the standard paediatric Crosby capsule. 6 perforations occurred, all in a group of 65 biopsies of children weighing less than $10 \mathrm{~kg}$. (9\%). The perforation risk in infants weighing less than $8 \mathrm{~kg}$. was $15 \%$ (4 perforations in 26 biopsies): in babies under $6 \mathrm{~kg}$. in weight it was 33\% ( 3 perforations from 9 biopsies). The authors thought that physiological and pathological thinness of the intestine contributed largely to the results. They recommended that a biopsy instrument with a smaller $(1.5-2 \mathrm{~mm}$.) port should be used, with resulting smaller quantities of tissue. Shiner (1963) advised that an instrument with an oval $(2 \mathrm{~mm} . \times 3 \mathrm{~mm}$.) port should be used in small children.

The need for caution is therefore real, and small children should never be submitted to biopsy as out-patients. The present series included 42 children less than 2 years of age, 40 children weighing less than $10 \mathrm{~kg}$., and a total of 47 children 'at risk' because of age, or weight, or both. Of the children outside this group, 24 were below the third centile for weight at the time of biopsy. 67 of the 96 specimens were histologically abnormal $(69 \%)$, and $53(55 \%)$ showed villous atrophy of varying severity (Table II). Why the present results should

TABLE II

Biopsy Specimens: Sites and Histology

\begin{tabular}{c|c|c|c}
\hline \multirow{2}{*}{ Site } & \multirow{2}{*}{ Totals } & \multicolumn{2}{|c}{ Histology } \\
\cline { 3 - 4 } & & Abnormal & Villous Atrophy \\
\hline $\begin{array}{l}\text { Distal duodenum } \\
\text { Proximal jejunum }\end{array}$ & 13 & 83 & 6 \\
\hline
\end{tabular}

differ so much from those of Partin and Schubert is not clear. Nevertheless, by the technique described, it is suggested that weight or age need not be a contraindication to suction biopsy in small children.
Sheldon and Tempany (1966), in a series of 92 biopsies of coeliac children, met three major complications; one perforation, one of severe melaena, and one case in which the knife failed to cut cleanly through the mucosa, so that the capsule remained adherent to the jejunal wall. Their failure rate was relatively high (35\%), the last 63 biopsies being obtained by a Crosby capsule after 97 attempts. Pyloric hold-up was the most frequent cause of failure; in others the capsule failed to fire. The authors felt that these results made intestinal biopsy of coeliac children unjustifiable as a routine procedure. 11 failures in 57 attempts $(19 \%)$ were recorded by Cameron and colleagues (Cameron, Astley, Hallowell, Rawson, Miller, French, and Hubble, 1962). McNicholl and Egan (1964) had 5 failures when biopsying 23 children $(22 \%)$. Series of biopsies in children have been described with a high success rate and few complications, but in these the numbers of infants were small-48 biopsies in 29 children, 5 under 2 years, with an $80 \%$ success rate and no complications (Kauder and Bayless, 1964); 27 successful biopsies in children, 12 under 2 years and here the success rate was not recorded (Pittman, Ores, Denning, and Cohen, 1964); a series of 42 successful biopsies included 12 children weighing between 5 and $10 \mathrm{~kg}$. and had no complications (Hamilton, 1966). Shiner (1963) reported 104 successful biopsies in children, but no details of ages, weights, or success rates were given.

The success rate in the present series, 96 out of $106(90 \%)$, was comparable to that in adults (Sheehy, 1964). Two patients required three attempts at biopsy: the first was a mentally defective hyperkinetic coeliac boy aged 3 years, difficult to sedate, who pulled the capsule from his stomach twice; the other was a microcephalic boy of 12 years, with idiopathic dilatation of stomach and small intestine, in whom pyloric obstruction occurred twice. Simple pyloric obstruction explained the 6 single failures, of which 3 occurred in the 40 patients weighing less than $10 \mathrm{~kg}$. In one patient, a boy of 10 years, a small quantity of fresh blood was found in the capsule after firing. $X$-ray examination of the abdomen showed it to be normal, tests for faecal occult blood were negative, and his clinical state remained unremarkable.

Sheldon and Tempany had several cases in which the capsule failed to fire, but this was not a problem in the present studies. It is considered important by the author to fill the capsule with air before firing; the soft and easily distended rubber diaphragm ensured efficient triggering.

The intestinal capsule will stop at a point where friction equals the propulsive force of peristalsis 
(Crosby, 1963). In a small group of patients submitted to biopsy before this series began, the Crosby capsule was used with conventional polythene tubing. The increased 'wiriness' of this tubing caused pyloric obstruction readily, and the jejunum was difficult to reach. These problems largely disappeared when the soft and pliable radio-opaque tubing was used, so that 83 of the 96 specimens $(86 \%)$ were from the proximal jejunum. The polyethylene tubing used by Sheldon and Tempany, and the Odman-Ledin catheter used by Anderson, may have caused excessive resistance to forward passage of the capsule, with resulting pyloric or duodenal obstruction.

In the present series, the position of the capsule was checked before firing, and adjusted if necessary, by screening on an image intensifier. The radiation dose to the skin was measured: 16 seconds of screening was found to be equivalent to one posteroanterior $x$-ray examination of the abdomen $(116 \mathrm{mr})$. The capsule was in most cases already in the jejunum on first screening and it was seldom that more than 10 seconds of screening time were necessary. This method is therefore more effective and subjects the patient to less radiation than the conventional one or two radiographs.

\section{Summary}

Recent work has suggested that small bowel biopsy in infants and children is difficult and hazardous. Pyloric or duodenal obstruction has been common.

A technique is described, using the standard paediatric Crosby capsule with soft radio-opaque tubing, which has a $90 \%$ success rate, even in infants. No serious complications occurred. The jejunum was reached in $86 \%$ of cases.

It is a pleasure to thank Dr. R. A. Shanks and Professor J. H. Hutchison for permission to study children under their care, and Drs. S. P. Rawson and E. M. Sweet for radiological facilities.

\section{REFERENCES}

Anderson, C. M. (1966). Intestinal malabsorption in childhood. Arch. Dis. Childh., 41, 571.

Cameron, A. H., Astley, R., Hallowell, M., Rawson, A. B., Miller, C. G., French, J. M., and Hubble, D. V. (1962). Duodenojejunal biopsy in the investigation of children with coeliac disease. Ouart. F. Med., 31, 125.

Crosby, W. H. (1963). Small intestinal studies: methods for obtaining intraluminal contents and intestinal mucosa. Amer. f. dig. Dis., 8, 2.

, and Kugler, H. W. (1957). Intraluminal biopsy of the small intestine: the intestinal biopsy capsule. ibid., 2, 236.

Hamilton, J. R. (1966). Risk of intestinal biopsy in infants. New Engl. F. Med., 274, 521.

Kauder, E., and Bayless, T. M. (1964). Peroral intestinal biopsy in children: a technique. Amer. F. Dis. Child., 107, 582.

Lanzkowsky, P., Wilson, J. F., and Lahey, M. E. (1963). Technique for peroral small intestinal biopsy in children. $\mathcal{F}$. Pediat., 63, 459.

McDonald, W. G. (1966). Perforation and haemorrhage after gastrointestinal mucosal biopsy in a child. Gastroenterology, 51, 390.

McNicholl, B., and Egan, B. (1964). Jejunal biopsy in childhood. Brit. med. F., 1, 57.

Partin, J. C., and Schubert, W. K. (1966). Precautionary note on the use of the intestinal-biopsy capsule in infants and emaciated children. New Engl. F. Med., 274, 94.

Pittman, F. E., Ores, C., Denning, C. R., and Cohen, H. I. (1964) A new method for use of the Crosby-Kugler intestinal mucosa biopsy capsule. Pediatrics, 34, 276.

Sheehy, T. W. (1964). Intestinal biopsy. Lancet, 1, 959.

Sheldon, W., and Tempany, E. (1966). Small intestine peroral biopsy in coeliac children. Gut, 7, 481.

Shiner, M. (1963). Jejunal biopsy in childhood. Brit. med. F., 2, 1200 . 